\title{
PURWARUPA SISTEM PEMANTAU DAN PERINGATAN KADAR GAS KARBON MONOKSIDA (CO) PADA KABIN MOBIL BERBASIS MIKROKONTROLER ATMEGA 8
}

\author{
Anggit Perdana $^{1)}$, Adian Fatchur Rochim ${ }^{2)}$, Eko Didik Widianto ${ }^{2)}$ \\ Program Studi Sistem Komputer, Fakultas Teknik, Universitas Diponegoro, \\ Jln. Prof. Sudharto, Tembalang, Semarang, Indonesia \\ email : aperdana08@gmail.com
}

\begin{abstract}
High growth in vehicle, contribute air pollution and reduce human health quality. One of pollutants that generated by motor vehicle emissions is carbon monoxide (CO). CO gas can cause health problems for humans, even if exposed to long periods time will cause death. Emission test devices have been widely available in many auto repair shops, but at the moment emission testing, only read gas source or emissions sources from the muffler hole. Cabin space usually escaped from checking, whether there is pollution that enters the cabin or not.

This final project has a purpose to design a carbon monoxide detector devices which will show the levels of carbon monoxide (CO) into 4 categories of air quality, that are safe, wary, watch out, and danger. System will automatically warning the driver if the gas exceeds the threshold. Microcontroller that used as the central data processing data is microcontroller Atmega 8, by ATMEL and use gas censor TGS 2442. Design begin with a hardware schematic and software design using BASCOM-AVR. Implementation phase include the implementation of the physical device, programs, and censor. Testing phase is done by testing the tool using 3 gas source, that are cigarette smoke, motorcycle exhaust, and car exhaust.

The test result showed that the highest error rate on these tool when compared with a comparable gas analyzer scott instruments is $6.46 \%$, with $93.54 \%$ accuracy rate. This CO gas monitor hasadvantage easily portable and include three actuators, that are LCD will show the levels of CO gas, buzzer will give warning sound when gas exceeds the threshold, and the vibrating motor provide tactile warning to the user.
\end{abstract}

Keywords: Carbon monoxide gas detector, Gas censor TGS 2442, LCD, Buzzer, Vibrating motor

\section{PENDAHULUAN}

\subsection{Latar Belakang}

Udara merupakan kebutuhan yang pokok guna menunjang kehidupan manusia dimuka bumi ini. Terkadang secara tidak langsung aktifitas yang dilakukan oleh manusia itu sendiri tidak melihat aspek keberlangsungan kelestarian lingkungan. Salah satu contoh nyata adalah penggunaan kendaraan bermotor secara besar-besaran, sehingga menyebabkan pencemaran udara. Zat yang terkandung dalam asap pembuangan knalpot salah satu diantaranya adalah gas karbon monoksida. Gas ini sangat berbahaya karena dapat menyebabkan gangguan kesehatan bahkan ditingkat yang lebih parah merupakan penyebab kematian manusia.

Masyarakat cenderung tidak mengetahui jika telah menghirup gas karbon monoksida, karena sifatnya tidak berwarna, berbau, dan berasa. Banyak kasus kematian secara tiba-tiba yang disebabkan oleh gas ini, terutama pada pengguna kendaraan roda empat.

\subsection{Tujuan}

Tujuan dari penelitian ini adalah merancang sebuah sistem yang mampu mendeteksi dan memberikan peringatan dini tentang bahaya gas karbon monksida (CO) kepada pengguna kendaraan roda empat.

\subsection{Pembatasan Masalah}

Penulis membatasi pembahasan pada penelitian ini pada topik sebagai berikut:

1. Sasaran penggunaan alat ini adalah di dalam kabin kendaraan roda empat.

2. Pengujian alat, dilakukan dengan cara mensimulasikan kabin mobil.

3. Alat hanya mendeteksi gas karbon monoksida (CO) menggunakan sensor gas TGS 2442.

4. Perilaku dari sistem hanya memberikan informasi mutu udara dan memberikan peringatan, jika kadar gas melampaui ambang batas.

5. Alat menggunakan mikrokontroler Atmega 8 sebagai pusat pengolahan data. 
6. Penelitian hanya membahas efek gas karbon monoksida (CO) terhadap manusia.

7. Perangkat keras bersifat purwarupa dan dapat disempurnakan ke depanya.

\section{Dasar Teori}

\subsection{Pengaruh Karbon Monoksida terhadap Manusia}

Karbon monoksida dengan rumus kimia $\mathrm{CO}$, merupakan gas yang dihasilkan dari pembakaran bahan bakar fosil. Karbon monoksida merupakan penyebab paling umum dalam kasus keracunan gas di berbagai negara. Efek dari keracunan gas ini adalah dapat mengakibatkan keracunan pada sistem syaraf pusat dan jantung.

Gejala paling ringan yang disebabkan oleh gas ini adalah pusing - pusing dan mual pada kosentrasi dibawah 100 ppm, sedangkan gejala yang paling berat adalah dapat menimbulkan kematian. Kadar yang diangggap langsung memberikan dampak berbahaya bagi kesehatan adalah $1500 \mathrm{ppm}^{[13]}$.

\subsection{Figaro 2442}

Figaro 2442 merupakan sensor pendeteksi gas karbon monoksida (CO) yang memiliki fitur sedikit mengkonsumsi daya, ukuran yang minimalis, dan sensifitas yang tinggi. Sensor ini bekerja pada tegangan referensi sebesar $5 \mathrm{~V}$ yang dihubungkan pada pemanas (Vh) dan Rs. Rs sendiri merupakan resistansi sensor yang terhubung pada pin 2 dan pin 3, selain sebagai tegangan referensi nilai Rs digunakan untuk input pada elemen pemanas (heater), pada pin 1 dan pin 2.

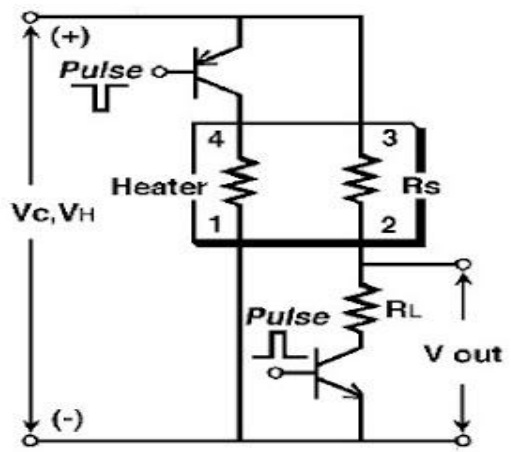

Gambar 1. Rangkain Dasar Sensor TGS $2442^{[18]}$

Hambatan sensor (Rs) dihitung dengan menggunakan persamaan berikut :

$\mathrm{Rs}=((\mathrm{Vcc} \times \mathrm{RL}) / \mathrm{Vout})-\mathrm{RL}$ dimana :

RL = Hambatan antara kedua elektroda sensor (Ohm)

Vcc = Tegangan rangkaian (Volt)

Vout $=$ Tegangan keluaran (Volt)

Rs $=$ Hambatan variable sensor $(\mathrm{Ohm})$

\subsection{Mikrokontroler Atmega 8}

Atmega 8 adalah mikrokontroler 8 bit keluaran ATMEL dengan konsumsi daya yang rendah. Atmega berbasis arsitektur RISC (Reduce Intruction Set Compiler) dengan kemampuan mengeksekusi intruksi yang kuat dalam satu siklus clock tunggal, dengan troughputs mendekati 1 MIPS per MHz. Mikrokontroler ini memiliki 28 pin dengan internal ADC yang terhubung ke dalam 8 channel Analog Multiplexer. Tegangan referensi untuk ADC diperoleh dari pin 21 (AREF) ${ }^{[3]}$.

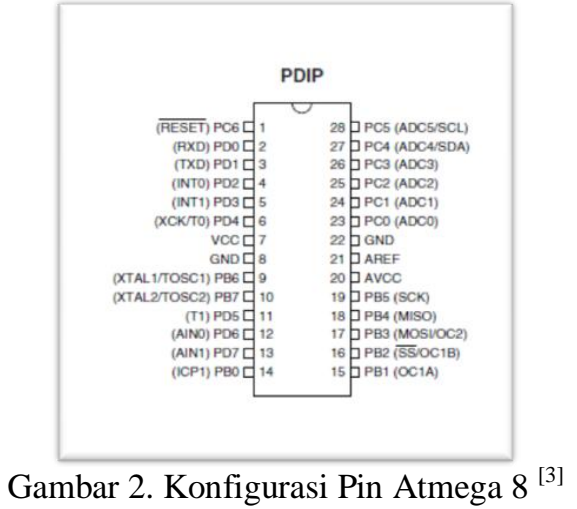

\subsection{Bahasa Pemrograman Mikrokontroler}

Bahasa pemrograman mikrokontroler dapat dibagi menjadi 3 kategori yaitu, bahasa tingkat rendah, bahasa tingkat menengah, dan bahasa tingkat tinggi. Mikrokontroler keluaran Atmega telah mampu menggunakan bahasa tingkat tinggi diantaranya adalah bahasa basic, bahasa $\mathrm{C}$, dan Pascal. Program ini ditulis menggunakan bahasa basic dengan compiler menggunakan BASCOMAVR.

\subsection{LCD $16 \times 2$ Baris}

Liquid Crystal Display (LCD) merupakan sebuah indikator output berupa tampilan layar. LCD M1632 16 x2 merupakan modul LCD dot matrix dengan konsumsi daya yang rendah. LCD M1632 memiliki sebuah pengontrol (driver) CMOS LCD, pengontrol tersebut terdiri dari Character Generator (CG) ROM / RAM, dan display data (DD) RAM. 


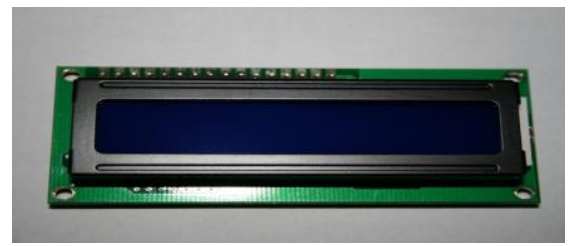

Gambar 3. Bentuk Fisik LCD 16 x 2

\section{Perancangan Sistem}

\subsection{Blok Diagram Rancangan Sistem}

Rancangan sistem dibagi kedalam tiga bagian yaitu, masukan, pemrosesan, dan keluaran. Piranti masukan menggunakan sensor TGS 2442 untuk mendeteksi gas karbon monoksida (CO). Data yang diperoleh dari hasil pembacaan sensor TGS 2442 terhadap gas karbon monoksida (CO), akan diteruskan ke piranti keluaran dengan sebelumnya data diproses oleh mikrokontroler.

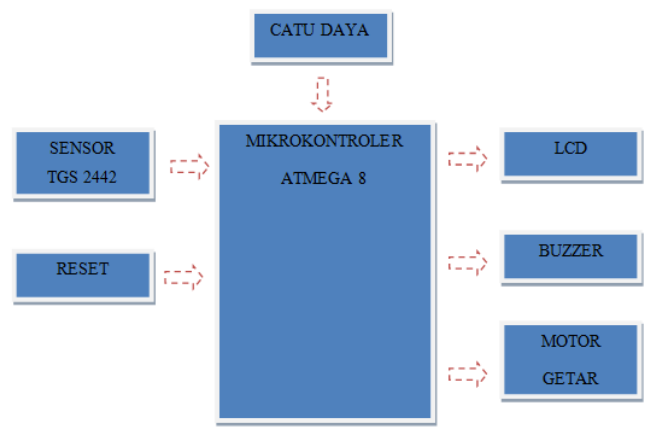

Gambar 4. Diagram Blok Sistem

\subsection{Rangkaian Mikrokontroler Atmega 8}

Rangkaian mikrokontoler yang ditunjukan oleh gambar 5, memiliki 28 port. Port yang digunakan adalah port $\mathrm{C}$, port $\mathrm{B}$, dan port $\mathrm{D}$. Port C merupakan port ADC (Analog to Digital Converter) serta dapat dikonfigurasikan sebagai port I/O. Data analog dari sensor TGS 2442 akan diteruskan pada salah satu pin ADC yang tersedia di port C. Data yang telah dikirim akan dikonversikan ke bentuk data digital, dan untuk tahap selanjutnya akan diproses oleh mikrokontroler. Port B digunakan sebagai jalur pengiriman data ke LCD. Data yang dikirim dilakukan secara 4 bit. Skematik rangkaian mikrokontroler pada gambar 6 memiliki sebuah switch yang digunakan sebagai saklar untuk mengalirkan atau memutus arus dari sumber tegangan (adaptor).

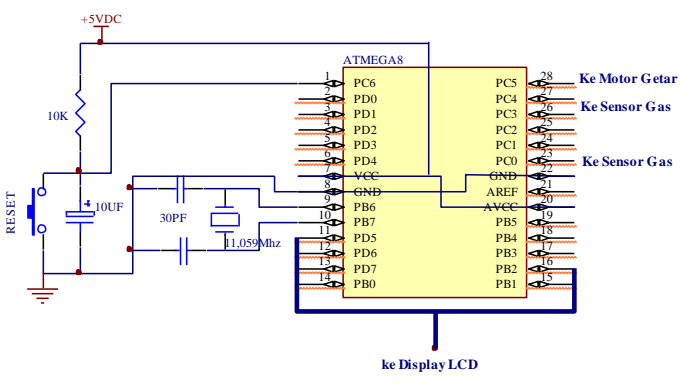

Gambar 5 Rangkaian Mikrokontroler Atmega 8

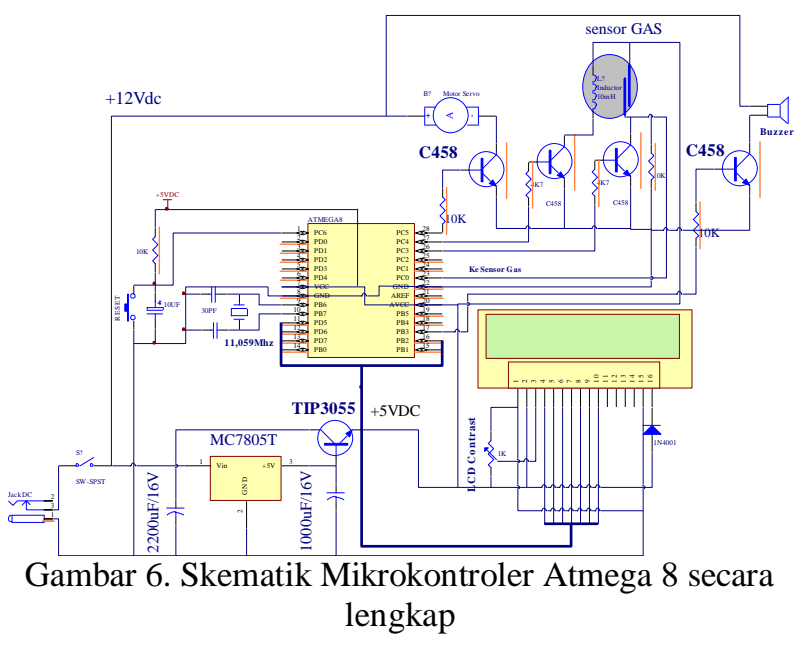

\subsection{Perancangan Software}

Tahapan perancangan software ini, menggunakan bahasa BASIC sebagai bahasa pemrograman dan BASCOM-AVR sebagai compiler. Tahap awal dalam perancangan software adalah membuat flowchart yang berfungsi sebagai acuan dan koreksi apabila terjadi kesalahan saat eksekusi program. Berikut flowchart sistem. 


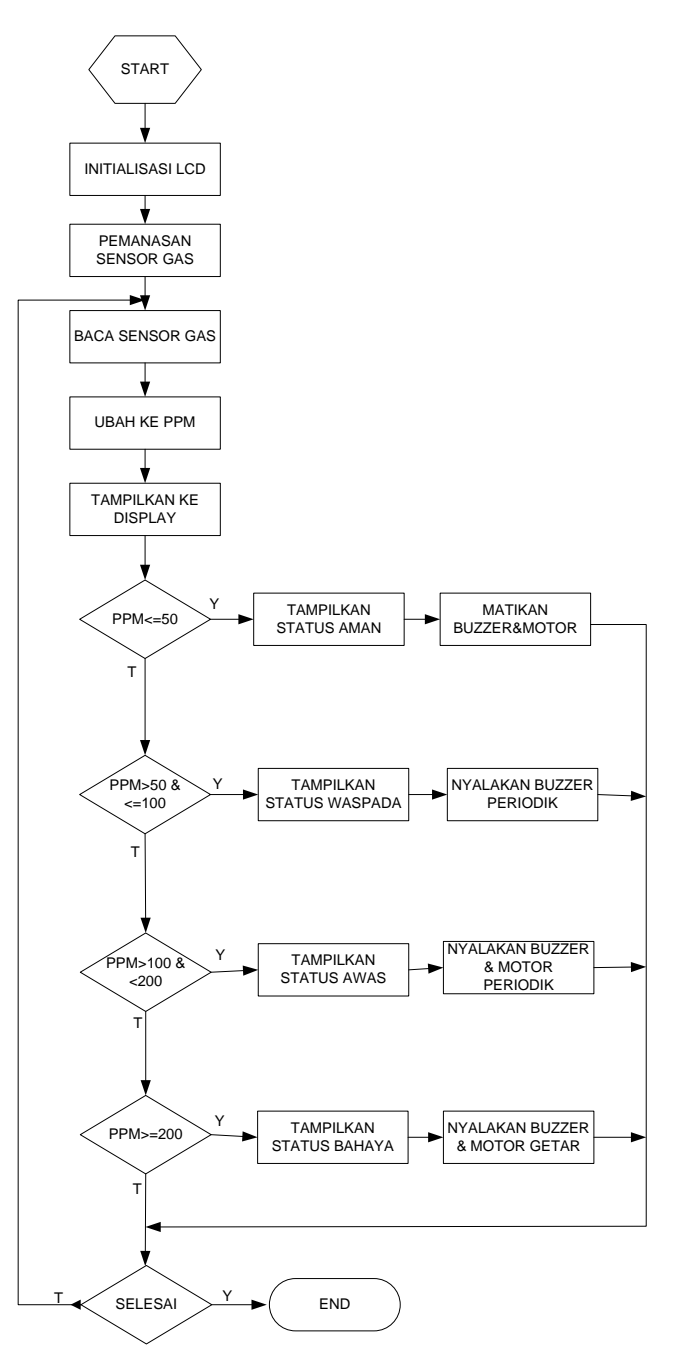

Gambar 7. Flowchart Sistem

\subsection{Pengkondisian Sinyal ADC}

Pengkondisian sinyal ini berfungsi untuk mengubah atau mengkonversi data analog yang diberikan oleh sensor menjadi data digital. Proses mengubah data analog menjadi data digital dikerjakan oleh ADC yang ada pada mikrokontroller Atmega8. Data yang dikeluarkan oleh sensor masih dalam bentuk tegangan, oleh karena itu digunakan rumus berikut :

Kode Digital $=($ Vinput $/$ Vref $) \times 1024$ 3.1

Vinput merupakan tegangan keluaran dari sensor, sedangkan Vref merupakan tegangan referensi untuk sensor sebesar $5 \mathrm{~V}$. Besarnya tegangan Vref sama dengan tegangan VCC. Nilai 1024 diperoleh dari resolusi besar bit $\mathrm{ADC}$ mikrokontroler Atmega 8 sebesar 10 bit, maka nilai desimalnya adalah $2^{\wedge} 10$ biner $=1024$ desimal.

\subsection{Perhitungan Kosentrasi Gas Karbon Monoksida}

Setelah semua rangkaian selesai dikerjakan, langkah selanjutnya adalah mencari rumus perhitungan kadar gas karbon monoksida (CO). Nilai dari gas karbon monoksida diperoleh dari perhitungan nilai Rs. Berdasarkan datasheet sensor TGS 2442, nilai dari Rs dapat dicari dengan menggunakan rumus berikut :

$$
\mathrm{Rs}=5-\mathrm{v} 1 / \mathrm{v} 1
$$

Merujuk pada datasheet sensor TGS 2442, nilai tegangan referensi sensor (Vref) adalah sebesar $5 \mathrm{~V}$. Sedangkan nilai Ro merupakan hambatan sensor pada konsentrasi gas karbon monoksida (CO) sebesar 100 ppm (part per million). Persamaan untuk menghitung gas karbon monoksida (CO) adalah sebagai berikut :

$$
\mathrm{CO}=100 / \mathrm{Rs} \mathrm{ppm}
$$

\section{Implementasi}

\subsection{Implementasi Alat}

Implementasi alat dibagi menjadi implementasi bentuk fisik alat, implementasi program, dan implementasi modul sensor. Keseluruhan dari rangkain elektronik dikemas dalam kotak plastik untuk melindungi perangkat elektronis rangkaian.

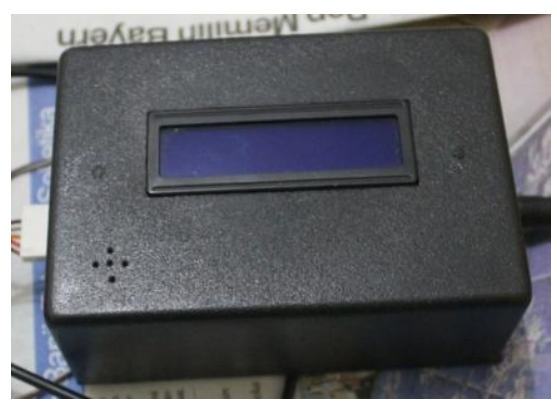

Gambar 8 Bentuk Fisik Alat Pemantau Gas CO

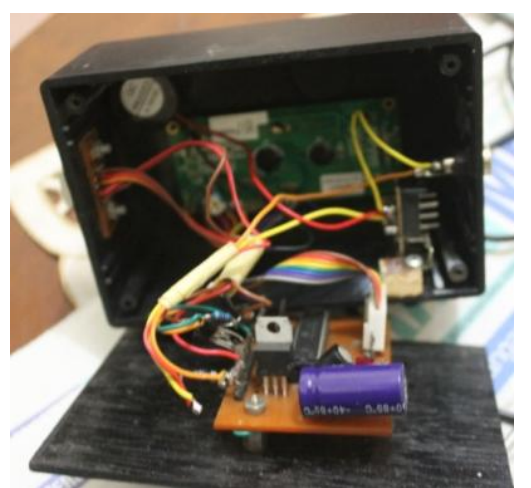

Gambar 9. Rangkaian Alat Pendeteksi Gas CO 


\subsection{Implementasi Program}

Tampilan awal program akan ditampilkan pada LCD berupa tulisan "Anggit Perdana L2N008006". Layar LCD hanya digunakan untuk menampilkan kadar gas karbon monoksida yang terdeteksi.

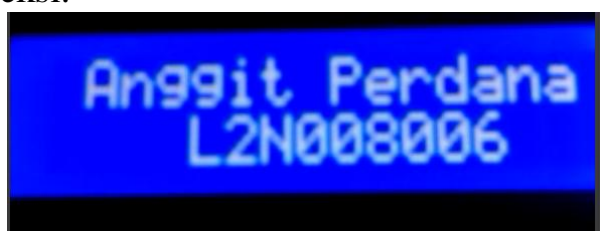

Gambar 10. Tampilan Awal Program

Tampilan waktu tunggu pemanasaran sensor akan ditampilkan setelah tampilan awal program telah selesai dieksekusi. Fungsi waktu tunggu ini bertujuan untuk memberikan waktu sensor membersihkan udara disekitarnya.

\section{Tunggu Pemanasan Hit Mundur :295}

Gambar 11. Tampilan Proses Pemanasan Sensor

Langkah selanjutnya adalah proses pembacaan sensor terhadap gas karbon monoksida.

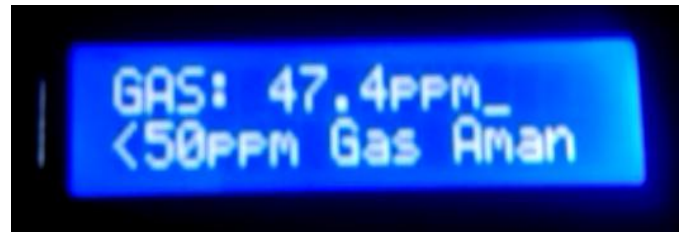

Gambar 12. Proses Pembacaan Sensor

\subsection{Implementasi Sensor}

Modul sensor TGS 2442 digunakan untuk mendeteksi kadar gas karbon monoksida (CO) dalam ruangan. Berikut hasil implementasi dari rangkaian sensor TGS 2442 .

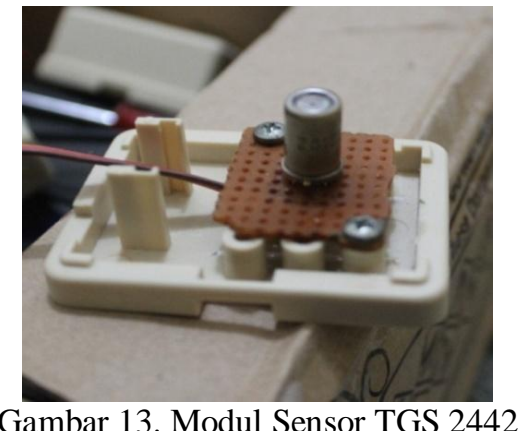

\section{Pengujian}

\subsection{Pengujian Menggunakan Asap Rokok}

Pengujian ini menggunakan asap rokok sebagai sumber gas karbon monoksida (CO). Asap dari hasil pembakaran tembakau selanjutnya akan disalurkan ke dalam kotak plastik yang digunakan sebagai wadah penampung gas. Tujuan dari pengujian alat menggunakan asap rokok sebagai sumber gas karbon monoksida (CO) adalah untuk mengetahui kandungan gas karbon monoksida (CO) dalam sebatang rokok.

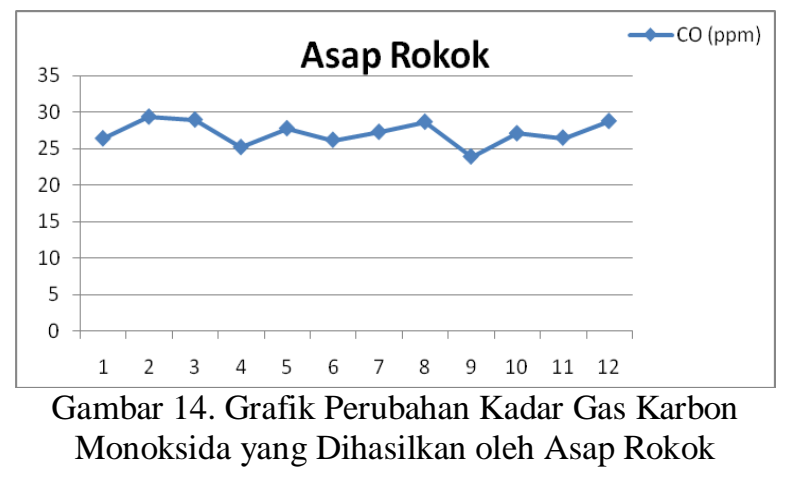

Grafik yang ditunjukan pada gambar 14, sumbu kordinat $y$ menunjukkan range nilai gas karbon monoksida (CO) dan kordinat $x$ menunjukkan banyaknya sampling yang dicuplik setiap 5 detik. Terlihat pada gambar 13 gas karbon monoksida (CO) yang dihasilkan oleh asap rokok memiliki kandungan gas tertinggi sebesar 29,4 ppm.

\subsection{Pengujian dengan Gas Buang Sepeda Motor}

Pengujian menggunakan emisi gas buang kendaraan sepeda motor bertujuan untuk mengetahui kadar gas karbon monoksida (CO) yang dihasilkan. Pengujian ini menggunakan sepeda motor Yamaha Mio Soul tahun pembuatan 2008. Proses pengujian dilakukan dengan meletakkan sensor TGS 2442 di dalam wadah penampung gas yang tertutup rapat. Langkah selanjutnya yaitu menyalakan alat pendeteksi gas karbon monoksida (CO), lalu mesin mulai dihidupkan. 


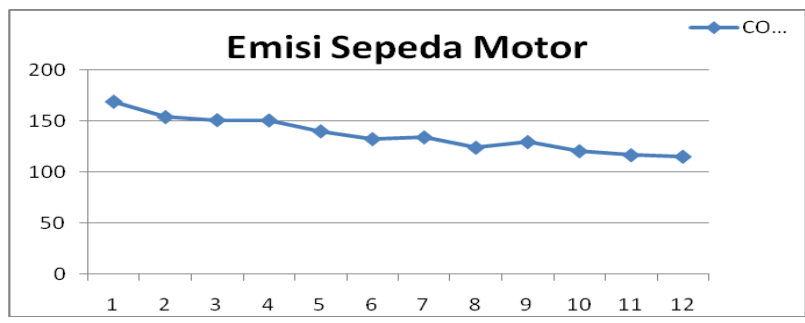

Gambar 15. Grafik Perubahan Kadar Gas Karbon

Monoksida yang Dihasilkan oleh Gas Buang Sepeda Motor

Grafik yang ditunjukkan pada gambar 15, sumbu kordinat $y$ menunjukkan range nilai gas karbon monoksida (CO) dan kordinat $x$ menunjukkan banyaknya sampling yang dicuplik setiap 5 detik. Terlihat pada gambar 15 gas karbon monoksida (CO) yang terbaca oleh sensor cenderung menurun. Hal ini disebabkan oleh beberapa macam faktor yang mengganggu proses pembacaan sensor. Salah satu faktornya adalah adanya uap air yang mengganggu proses pembacaan data oleh sensor.

\subsection{Pengujian dengan Menggunakan Gas Buang Mobil}

Pengujian yang terakhir, yaitu menggunakan sumber gas yang berasal dari gas buang kendaraan roda empat (Mobil). Mobil yang digunakan adalah Suzuki SX4 tahun pembuatan 2012. Sistematika pengujian kali ini sama seperti pengujian sebelumnya, hanya saja terdapat perbedaan pada sumber gas yang digunakan.

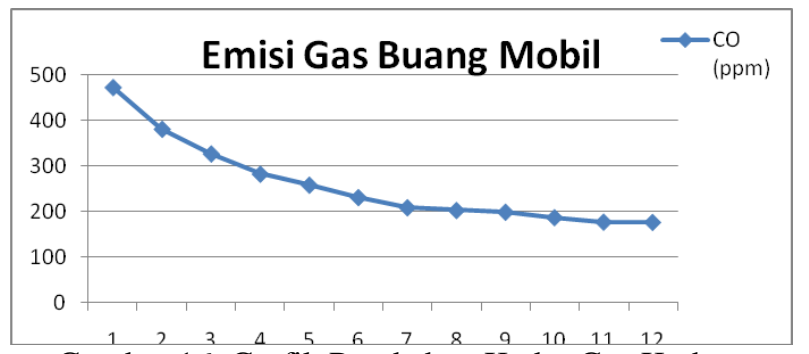

Gambar 16. Grafik Perubahan Kadar Gas Karbon

Monoksida yang Dihasilkan oleh Gas Buang Mobil

Grafik perubahan kadar gas karbon monoksida ditunjukkan pada gambar 16, cenderung mengalami penurunan. Penurunan kadar gas di dalam kotak penampung disebabkan adanya uap air yang mengganggu pembacaan sensor.

\subsection{Pengujian dengan Alat Pembanding}

Pengujian kali ini bertujuan untuk mengetahui apakah alat pemantau kadar gas karbon monoksida (CO) telah mampu memberikan data yang akurat. Pengujian dilakukan dengan menggunakan gas analyser yang telah tersertifikasi dan hasil dari masing-masing alat kemudian dibandingkan untuk mendapatkan selisih pembacaan data. Percobaan ini dilakukan di Laboratorium Teknik Lingkungan Universitas Diponegoro.

Gas analyser yang digunakan sebagai alat pembanding adalah gas analyser ScottScout Plated Multi Gas Detector. Gas analyser tersebut mampu mendeteksi kandungan gas $\mathrm{CO}, \mathrm{O}_{2}$, dan $\mathrm{HS} 2$, dimana tampilan gas bisa ditampilkan dalam ppm atau persen. Jangkaun pembacaan gas analyser scott instruments untuk gas karbon monoksida adalah 0-1500 ppm.

Tabel 1. Hasil Pengujian Perangkat dengan Gas Analyser Scott

\begin{tabular}{|c|c|c|c|c|}
\hline No. & $\begin{array}{c}\text { Alat } \\
\text { Pemantau } \\
\text { Gas CO }\end{array}$ & $\begin{array}{c}\text { Gas } \\
\text { Analyser } \\
\text { Scott }\end{array}$ & Selisih & $\begin{array}{c}\text { Error } \\
\%\end{array}$ \\
\hline 1. & $26,3 \mathrm{ppm}$ & 24,6 & 1,7 & $\begin{array}{c}6,46 \\
\mathrm{ppm}\end{array}$ \\
\hline 2. & $22 \mathrm{ppm}$ & $\begin{array}{c}21,2 \\
\mathrm{ppm}\end{array}$ & 0,8 & $\begin{array}{c}3,64 \\
\%\end{array}$ \\
\hline 3 & $18,5 \mathrm{ppm}$ & 17,9 & 0,6 & $\begin{array}{c}3,24 \\
\mathrm{ppm}\end{array}$ \\
\hline
\end{tabular}

Data pada tabel di atas merupakan hasil pengukuran dan pembandingan antara alat yang dikerjakan penulis dengan gas analyser scott instruments. Kendala yang dihadapi saat melakukan percobaan adalah perbedaan waktu pencuplikan data, sryaitu alat yang dibuat oleh penulis menampilkan data setiap lima detik sedangkan gas analyser scott instruments menampilkan data setiap detik. Adanya kendala demikian, data dari gas analyser scott instruments dihitung nilai rata-ratanya setiap 5 detik.

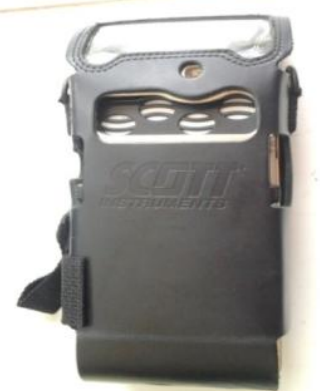

Gambar 17. Bentuk Fisik Gas Analyser Scott 


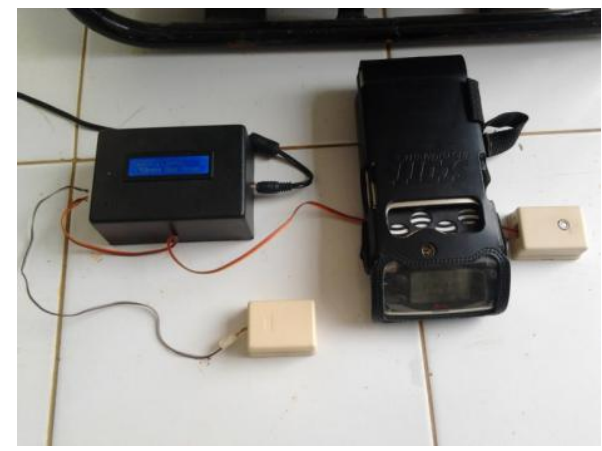

Gambar 18. Tampilan Alat pemantau Gas CO dan Gas Analyser Scott

V1. PENUTUP

6.1. Kesimpulan

1. Alat secara umum telah mampu bekerja sesuai dengan perancangan.

2. Sistem telah mampu menghidupkan buzzer dan motor getar sesuai dengan rancangan.

3. Berdasarkan pengujian dengan menggunakan tiga macam sumber gas, sumber gas yang menggunakan gas buang mobil memiliki kandungan karbon monoksida paling tinggi, sehingga memerlukan perhatian secara khusus.

4. Uap air yang dihasilkan dari gas buang kendaraan dapat mengganggu proses pembacaan sensor.

5. Alat pendeteksi gas karbon monoksida (CO) telah ditera di Laboratorium Teknik Lingkungan Universitas Diponegoro, dengan hasil kesalahan tertinggi sebesar $6,46 \%$.

\subsection{Saran}

Adapun saran yang dapat diberikan sehubungan dengan pelaksanaan penelitian ini adalah sebagai berikut.

1. Alat pemantau gas karbon monoksida (CO) ini dapat dikembangkan lebih lanjut dengan menambahkan sistem aktuator yang mampu mengurangi kandungan gas di dalam ruangan secara otomatis.

2. Dibutuhkan standarisasi secara berkala untuk menjaga validasi keluaran alat pemantau gas karbon monoksida (CO).

\section{DAFTAR PUSTAKA}

[1] Anggraeni, Nur Ika Setyowati, Pengaruh Lama Paparan Asap Knalpot dengan Kadar CO 1800 Ppm terhadap Gambaran Hispatologi Jantung pada Tikus Wistar, Laporan Akhir Penelitian Karya Tulis Ilmiah, Universitas Diponegoro Semarang, 2009.

[2] Ardabili, Muhamad, Rancang Bangun Alat Pendeteksi Kebocoran Gas dari Bensin atau Solar pada Kabin Mobil, Skripsi Jurusan Fisika Fakultas Sains dan Teknologi, Universitas Islam Negeri Maulana Malik Ibrahim Malang, 2010.

[3] Atmega8, DataSheet, No. Rev. 2486VAVR-02/11, Juli 2012.

[4] Budiharto, Widodo, Panduan Lengkap Belajar Mikrokontroler Perancangan Sistem dan Aplikasi Mikrokontroler, PT. Elex Media Komputindo, Jakarta, 2005.

[5] http://id.wikipedia.org/wiki/Bahan bakar fosil/21 Februari 2013, 18.00 WIB.

[6] http://id.wikipedia.org/wiki/Bensin/ 21 Februari 2013, 20.00 WIB.

[7] http://otomotif.antaranews.com/beritaotomotif/1340022667/gaikindo-686-persenpopulasi-mobil-di-jawa/ 21 Februari 2013, 23.00 WIB.

[8] Iswanto, Belajar Sendiri Mikrokontroler AT90S2313 dengan BASIC Compiler, Penerbit Andi Offset, Yogyakarta, 2009.

[9] Komite Penghapusan Bensin Bertimbal, Januari 2008.

[10] Kuncoro, YB Ari, Alat Pemantau Kadar Gas CO di Udara Berbasis Mikrokontroler Atmega 8535, Skripsi Jurusan Teknik Elektro Fakultas Sains dan Teknologi Universitas Sanata Dharma Yogyakarta, 2011.

[11] Omaye ST Ph.D., Metabolic Modulation of Carbon Monoxide Toxicity, Department of Nutrition and Environmental Toxicology and Healty Track University of Nevada, Reno, NV 89557, USA, 2002.

[12] Satrio, Irfan Aulino Budi., Detektor Emisi Gas Buang dalam Mobil dengan

Dukungan Antarmuka Komunikasi Serial, Skripsi Jurusan Teknik Elektro Fakultas Teknik Universitas Diponegoro Semarang, 2006.

[13] Sentra Informasi Keracunan Badan POM, Pedoman Penatalaksanaan Keracunan Untuk Rumah Sakit, Karbon Monoksida, Jakarta, 2001. 
[14] Setiawan, Afrie, 20 Aplikasi Mikrokontroler Atmegal6 Menggunakan BASCOM - AVR, Andi Offset, Yogyakarta, 2011.

[15] Setiawan, Iwan ST, MT., Buku Ajar Sensor dan Tranduser. Fakultas Teknik Universitas Diponegoro, Semarang, 2009.

[16] Sudjadi, ST, MT., Teori dan Aplikasi Mikrokontroler, Graha Ilmu, Yogyakarta, 2005.

[17] Tarigan, Ir. Permatin, M.Sc., Sistem Tertanam, Graha Ilmu, Yogyakarta, 2010.

[18] TGS 2442-for the detection of Carbon Monoxide, FIGARO, DataSheet.

[19] Wardhana, W. A., Teknik Analisis Radioaktivitas Lingkungan, Andi Offset, Yogyakarta, 1994.

\section{BIODATA PENULIS}

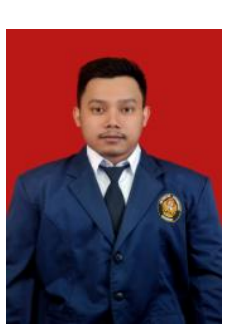

Anggit Perdana, lahir di Purbalingga 23 Juli 1990. Menempuh pendidikan dasar di SD N Losari Rembang Purbalingga. Melanjutkan ke SMP N 1 Rembang Purbalingga, Dan Pendidikan tigkat atas di SMA N 2 Purbalingga, lulus tahun 2008. Dari tahun 2008 sampai saat ini tengah menyelesaikan pendidikan Strata Satu di Program Studi Teknik Sistem Komputer, Universitas Diponegoro, Semarang, Indonesia Angkatan Tahun 2008. 